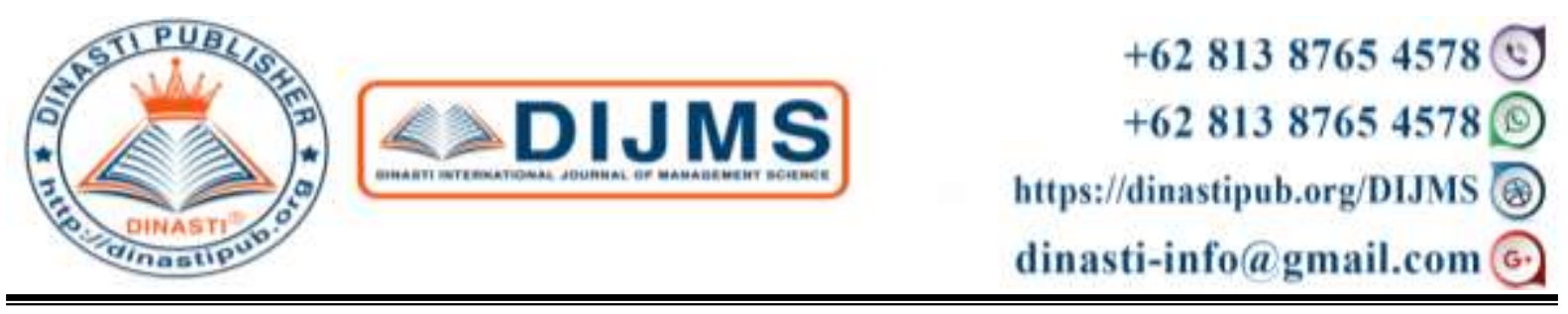

\title{
THE INFLUENCE OF KNOWLEDGE MANAGEMENT ON ORGANIZATIONAL PERFORMANCE WITH ERP IMPLEMENTATION AS MEDIATOR
}

\author{
Derri Muhammad Ramdani ${ }^{1}$, Hady Siti Hadijah ${ }^{2}$ \\ 1) Universitas Pendidikan Indonesia, Bandung, Indonesia \\ ${ }^{2)}$ Universitas Pendidikan Indonesia, Bandung, Indonesia
}

\begin{tabular}{|c|c|}
\hline $\begin{array}{l}\text { ARTICLE INFORMATION } \\
\text { Received: } 19 \text { February } 2020 \\
\text { Revised: } 25 \text { February } 2020 \\
\text { Issued: } 02 \text { March } 2020 \\
\text { (filled in by Editor) } \\
\text { Corresponding author: first author } \\
\text { E-mail: } \\
\text { emailderri@ gmail.com } \\
\text { hady@upi.edu }\end{array}$ & $\begin{array}{l}\text { Abstract: This study examines whether knowledge } \\
\text { sharing has influence on organizational performance, } \\
\text { where Enterprise Resource Planning (ERP) is used as } \\
\text { a mediator connecting these two variables. ERP system } \\
\text { is unique because it requires users who have more } \\
\text { knowledge and have special skills, in contrast to usual } \\
\text { users who usually do their job manually. In corporation } \\
\text { world, an integrated system like ERP should be well- } \\
\text { socialized at maximum rate to reach performance } \\
\text { effectiveness and efficiency that will surely result in } \\
\text { organizational productivity. Nonetheless, in many } \\
\text { organizational cases there are still numerous } \\
\text { employees who decline to share knowledge in } \\
\text { regeneration process due to their fears of being } \\
\text { replaced by younger ones and this keeps the } \\
\text { knowledge sharing process on hold. With total of 500 } \\
\text { employees in a textile company in Bandung County, } \\
\text { the writer takes } 250 \text { samples as the population } \\
\text { representation. Data analysis is undergone through } \\
\text { Structure Equating Model (SEM) with assistance of } \\
\text { SPSS application, the writer can see the relationship of } \\
\text { knowledge sharing and its influence on organizational } \\
\text { performance. }\end{array}$ \\
\hline
\end{tabular}

\section{INTRODUCTION}

As the competition in business keeps escalating over time, demanding awareness of knowledge resources importance as companies' intellectual capital to reach competing advantage. Knowledge holds a very important role in increasing performances within company's elements. The research of goals implementation knowledge management towards 150 companies throughout Europe and US produced a conclusion: the existence of knowledge management results in collaboration increases, employees knowledge transfers, 
innovation increases, decision making increases, customers knowledge transfers, and not particular purpose. (The Conference Board, 2000).

One of the efforts that needs to be done in respect to develop the HR and knowledge uses (knowledge management) within employees to improve the organizational performance is innovation. (Setiarso, 2007). The Enterprise Resource Planning (ERP) program is one of many innovations in information technology area, ERP has been used by many companies in Indonesia due to its tangible success to ease working processes. By Definition, ERP is a tool used by companies to cut expenses and improve efficiency by integrating business processes and mutual resource sharing throughout the organization. ERP enables the company to have a more convergent insight from their information by integrating processes across functional and division lines by using centered database and integrated software module set (Scott and Kaindl, 2000; Zheng et al, 2000).

An increased organization productivity comes from productive employees and how they use knowledge management as their productive foundation. As what lies within knowledge management: creativity increases, knowledge sharing, and knowledge implementation which are perfected by ERP as supportive party from the whole organization productivity improvement process.

\section{LITERATURE REVIEW}

\section{Knowledge Management}

Knowledge Management is a means used by a company in identifying, producing, presenting, distributing, and enabling insight and experience adaptation. Insight and experience consist of knowledge; individually acquired knowledge, as well as the knowledge attached to the process or the company's standard procedure. The main objective of Knowledge Management is to effectively preserve and transfer the important knowledge to the employees. (Leung, Chan, \& Lee, 2003).

Based on Karl-Eric Sveiby (1998), Knowledge Management is an art to create values by leveraging intangible assets. Intangible assets are individual competency, internal structure such as system, procedure, and then last the organization patterns are external structure which consists of suppliers, customers, and others.

The Knowledge Management cycle in an organization was inspired by Polanyi, a chemist who first presented that knowledge consists of two kinds: tacit knowledge and explicit knowledge. Tacit knowledge is a knowledge that stays inside human mind in forms like intuition, judgment, skill, values and belief which are really hard to be formalized and shared to another people. Meanwhile, explicit knowledge is knowledge that has already been codified in document form or another form which are easier to transferred and distributed through any possible media. Explicit knowledge can be formulas, cassette/cd video and audio, product specification, or manual book as mentioned in Tobing (2007:21). Both knowledge is convertible through four conversion products: Socialization, Externalization, Combination, and Internalization. These four are also known as SECI Process (S:Socialization, Externalization, Combination, Internalization). Nonaka and Takeuchi (Setiarso, 2012:35). As mentioned in Liebowitz (1999), there are 3 (three) basic process in knowledge management implementation: knowledge creation, knowledge sharing, and knowledge implementing. Thus, from this section of literature review, it can be concluded 
that knowledge management implementation consist of those three, and the writer takes grand theory from Liebowitz as a foundation for this research.

\section{Organizational Performance}

Organizational performance is the totality of work result achieved by an organization. As achievement of organization goals indicates organizational performances, for how far is this organization could reach their goals in relation to goals that had been set before. (Surjadi, 2009:7).

\section{Indicators}

This research uses few indicators on each of its variable. On knowledge creation variable, the indicators are (a) socialization, (b) externalization, (c) combination, and (d) internalization. Then, in the knowledge sharing variable, the indicators will be (a) comparation, (b) consequences, (c) connections, and (d) conversations. On the next variable knowledge implementing, the indicators will be (a) patent, licensed technology (b) knowledge based customer service, (c) knowledge product and embedded technology, (d) separate KBS application product, and (e) knowledge workers at all level. For the third variable innovation the indicators are (a) process innovation, (b) product innovation, and (c) administration innovation. On the last variable organization, the indicators are (a) financial perspective, (b) internal perspective, (c) customer perspective, and (d) innovation \& learning perspective.

\section{Enterprise Resource Planning (ERP)}

Enterprise Resource Planning (ERP) as mentioned in O'Brien, J.A., \& Marakas, G. M. (2010:272) is a corporate system covering all functions in a company that are boosted by some integrated software module aims to support company's internal business process. For example, ERP software specialized for manufacturing company basically starts from processing incoming data, tracking sales status, inventory, goods shipping, and goods billing, also estimating raw materials and the need for human resources. James A. Hall (2011:31) mentioned ERP as an information system model that enables an organization to automate and integrate their main business process. Enterprise Resource Planning, as mentioned in Turban, Rainer, and Potter (2007:10) is designed to solve problems in information system functional area by integrating functional areas with the database. Based on definitions above, a conclusion can be made: Enterprise Resource Planning is an information system concept that integrates every module to support company's main business process.

\section{RESEARCH METHODS}

The method used for this research is quantitative method, and SEM (Structure, Equating Model) used for the data analysis. The research object consists of three variables: Knowledge Management, Organizational performance, and Enterprise Resource Planning (ERP). The Knowledge Management variable is an independent variable, symbolized by $\mathrm{X}$ which will be descended into three smaller dimensions $\mathrm{X} 1, \mathrm{X} 2, \mathrm{X} 3$. Organizational performance is a dependent variable symbolized by $\mathrm{Y}$ and Enterprise Resource Planning (ERP) is a connecting variable or mediator symbolized by Z. Based on explanation above, the conceptual framework paradigm will be described through the following picture: 


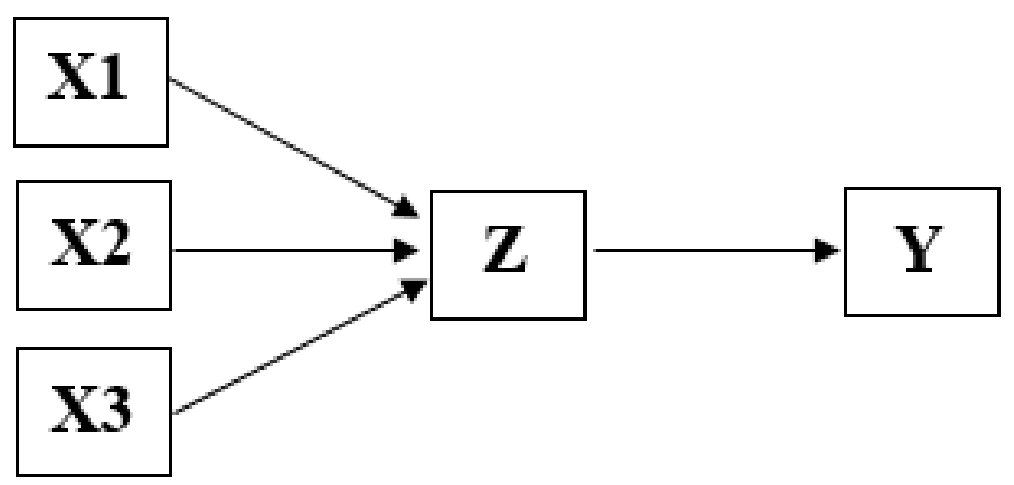

Picture 1. Conceptual Framework Paradigm.

Information:

$\begin{array}{lll}\mathrm{X} & = & \text { Knowledge Management } \\ \mathrm{X} 1 & = & \text { Knowledge Creation } \\ \mathrm{X} 2 & = & \text { Knowledge Sharing } \\ \mathrm{X} 3 & = & \text { Knowledge Implementing } \\ \mathrm{Y} & = & \text { Organizational performance } \\ \mathrm{Z} & = & \text { Enterprise Resource Planning } \\ \longrightarrow & = & \text { Symbolization of Influence }\end{array}$

\section{Major Hypothesis:}

"Knowledge Management generally has influence on the Organizational performance through the Enterprise Resource Planning (ERP) program".

\section{Minor Hypothesis:}

$\mathrm{H} 1=$ "Knowledge Creation as dimension of Knowledge Management has influence on the Organizational performance through the Enterprise Resource Planning (ERP) program".

$\mathrm{H} 2$ = "Knowledge Sharing as dimension of Knowledge Management has influence on the Organizational Performance through the Enterprise Resource Planning (ERP) program".

$\mathrm{H} 3$ = "Knowledge Implementing as dimension of Knowledge Management has influence on the Organizational Performance through the Enterprise Resource Planning (ERP) program".

$\mathrm{H} 4=$ "Knowledge Creation as dimension of Knowledge Management has no influence on the Organizational Performance through the Enterprise Resource Planning (ERP) program".

H5 = "Knowledge Sharing as dimension of Knowledge Management has no influence on the Organizational Performance through the Enterprise Resource Planning (ERP) program".

H6 = "Knowledge Implementing as dimension of Knowledge Management has no influence on the Organizational Performance through the Enterprise Resource Planning (ERP) program".

$\mathrm{H} 7$ = "Knowledge Management generally has no influence on the Organization Performance through the Enterprise Resource Planning (ERP) program". 


$$
\begin{aligned}
\mathrm{H} 0= & \text { "Employees' working motivation has no positive influence on } \\
& \text { employees'working productivity". } \\
\mathrm{H} 1= & \text { "Employees'working motivation has positive influence on employees'working } \\
& \text { productivity". }
\end{aligned}
$$

\section{FINDINGS AND DISCUSSION}

Analysis of Knowledge Management Influence on the Organizational Performance through Enterprise Resource Planning (ERP) program is explained based on the result of the calculation of multiple regression analysis using Structure Equating Model (SEM) so it will be possible to see the resulting correlation between the variables. This research is undergoing hypothesis testing with stastitic analysis, so that the existing research hypothesis is transformed to null hypothesis. This null hypothesis will be tested later through statistic analysis. This research uses multiple regression analysis where there are more than one independent variables for predicting dependent variable. Based on the calculation, the result is as the following:

Table 1. Significance test result

\begin{tabular}{lccc}
\hline \multicolumn{1}{c}{ Model } & $\begin{array}{c}\text { R } \\
\text { Square }\end{array}$ & $\begin{array}{c}\text { R } \\
\text { Square } \\
\text { Change }\end{array}$ & $\begin{array}{c}\text { Sig. F } \\
\text { Change }\end{array}$ \\
\hline $\begin{array}{l}\text { Knowledge } \\
\begin{array}{l}\text { Creation } \\
\text { Knowledge }\end{array}\end{array}$ & 0.119 & 0.119 & $0.000^{*}$ \\
$\begin{array}{l}\text { Sharing } \\
\text { Knowledge } \\
\text { Implementing }\end{array}$ & 0.255 & 0.137 & $0.000^{*}$ \\
ERP & 0.328 & 0.072 & $0.000^{*}$ \\
\hline
\end{tabular}

Knowledge Creation variable has significance value as much as $11.9 \%$ to the Organizational performance through Enterprise Resource Planning (ERP) with 0.000 significance, which means this contribution is significant.

Knowledge Sharing variable has significance value as much as $13.7 \%$ to the Organizational performance through Enterprise Resource Planning (ERP) with 0.000 significance, which means this contribution is significant.

Knowledge Implementing variable has significance value as much as $7,2 \%$ to the Organizational performance through Enterprise Resource Planning (ERP) with 0.000 significance, which means this contribution is significant.

Enterprise Resource Planning (ERP) variable has significance value as much as $10.1 \%$ to the Organizational performance with 0.000 significance, which means this contribution is significant.

From the data above, a conclusion can be made that all the hypotheses have been accepted even though there is an underperforming significance value, such as in Knowledge Implementing which has $7,2 \%$ to the Organizational performance. This thing happens because not all the employee were really implementing or applying the knowledge they have into their working system, they hesitated if they do what they know willingly, they would 
have been taken for granted and not getting the deserved compensantion from the employer which can be count as a loss for them.

The highest scoring variable in significance value is Knowledge Sharing which means a lot of employees did the knowledge sharing in their working system and this has significant influence on the organizational performance globally.

\section{CONCLUSION AND SUGESTION}

This research conclude a result that all the $\mathrm{X}$ variables consist of Knowledge Creation, Knowledge Sharing, and Knowledge Implementing has significant influence on the Organizational performance through the implementing of Enterprise Resource Planning (ERP) program. There are numerous facts on field and research concept found during the data collecting, so that the writer would like to give some suggestions for further research as follows: sampling technique can be taken and categorized based on divisions and departments, as well as the ranking diffence for corporate officer which could enable the value differentiations. For example, a supervisor who has obligation to share knowledge to his staffs contrasts to his staff who has no obligation to do so. Therefore, corporate officer rank or level could be included as subject characteristics in the further research.

\section{REFERENCE}

Andi. Kamasak, Rifat dan Fusun Bulutlar. (2010). The influence of knowledge sharing on innovation 22 (3): 306-317.

Aulawi, Hilmi et al.,. (2009). Hubungan Knowledge Sharing Behavior dan Individual Innovation Capability 11 (2): 174-187.

Chen, Chung-Jen et al.,. (2010). Knowledge management and innovativeness. The role of organizational climate and structure 31 (8): 848-870.

Daghfous, A. (2003). How to make knowledge management a firm's core capability? Journal of Knowledge Management Practice, 4.

Davenport, T., \& Klahr, P. (1998). Managing customer support knowledge. California Management Review, 40(3), 195-208.

Davenport, T., \& Prusak, L. (1998). Working knowledge: How organizations manage what they know. MA: Harvard Business School Press.

DeCarolis, D. M., \& Deeds, D. L. (1999). The impact of stocks and flows of organizational knowledge on firm performance: An empirical investigation of the biotechnology industry. Strategic Management Journal, 20(10), 953-968.

Deshpande, R., Jarley, U., \& Webster, F. (1993). Corporate culture, customer orientation and innovativeness in Japanese firms: A quadrad analysis. Journal of Marketing, 57, 23-37.

Desouza, K. C., \& Awazu, Y. (2006). Knowledge management at SMEs: Five peculiarities. Journal of Knowledge Management, 10(1), 32-43.

Drew, S. (1997). From knowledge to action: The impact of benchmarking on organizational performance. Long Range Planning, 30(3), 427-441.

Dyer, J. H., \& Singh, H. (1998). The relational view: Cooperative strategy and sources of interorganizational competitive advantage. Academy of Management Review, 23(4), 


\section{$660-679$.}

Gera, and Gu. 2004. The Effect of Organizational Innovation and Knowledge implementingon Firm Performance. International Productivity Monitor No. 9. Canada.

Girniene, Ingrida. 2012. Knowledge Management Influence on Innovation: Theoretical Analysis of

Organizational Factors. Copyright proceedings of the European Conference on Knowledge

Management: Academic Conferences \& Publishing International Ltd. Vilnius: Vilnius

University. Lithuania.

Inkinen, and Kianto. 2015. Knowledge Management Practices and Firm Performance: Empirical

Findings From Finland. Lappeenranta: Lappeenranta University of Technology. Finland.

Jafari, Akhayan and Mortazaei. 2009. A Review On Knowledge Management Discipline: Empirical

Kenfac, Nekoumanesh, and Yang. 2013. Process Innovation: Impacts on Organization's Performance( A Qualitative Study of Four Swedish Municipalities). Linnaeus University School of Business and Economics. Swedish.

Nonaka \& Konno. 1998. The Concept of "BA": Building A Foundation For Knowledge Creator.

Ghozali, Imam. (2012). Aplikasi Analisis Multivariative dengan Program IBM SPSS 20. Semarang: Undip.

Ghozali,Imam. (2008). Structural Equation Modeling Metode Alternatif dengan Partial Least Square (PLS). Edisi Kedua. Semarang: Badan Penerbit Universitas Diponegoro.

Gomes, F, C. (2003). Manajemen Sumber Daya Manusia. Yogyakarta

Mahmudi. (2010). Manajemen Kinerja Sektor Publik. Edisi Kedua. Yogyakarta: UPP STIM YKPN.

Marques, D. V. et al.,. (2008). Knowledge sharing networks and performance. Comportamento Organizacional E Gestao 14 (2): 162-192.

Matzler, Kurt et al.,. (2008). Personality Traits and Knowledge Sharing. Journal Of EconomicPsychology 29 (3): 301-313.

Nawawi, Hadari. (2006). Evaluasi dan Manajemen Kinerja di Lingkungan Perusahaan dan industri. Yogyakarta: Gadjah Mada University Press.

Setiarso, Bambang. (2006). Manajemen pengetahuan (knowledge management) dan proses penciptaan pengetahuan. (Online), Ilmu komputer.org.

Setiarso, Bambang. (2007). Penerapan Knowledge Management di Organisasi. Ilmu komputer.

Sun, Hongyi dan Pei-Lee Teh. (2011). Knowledge sharing, job attitudes and organizational citizenship behaviour. Industrial Management \& Data Systems 112 (1): 64-82.

Edvinsson, L., \& Malone, M. S. (1997). Intellectual capital - realizing your company's true value by finding its hidden roots. NY: Harper Business. 
Fiol, C. M., \& Lyles, M. A. (1985). Organizational learning. Academy of Management Review, 10(4), 803-813.

Friedman, R. A., \& Krackhardt, D. (1997). Social capital and career mobility: A structural theory of lower returns to education for Asian employees. Journal of Applied Behavioral Science, 33(3), 316-334.

Garvin, D. A. (1993). Building a learning organization. Harvard Business Review, 71(4)

Gold, A. H., Malhotra, A., \& Segars, A. H. (2001). Knowledge management: An organizational capabilities perspective. Journal of Management Information Systems, $18(1), 185-214$.

Grant, R. M. (1996a). Prospering in dynamically competitive environments: Organizational capability as knowledge integration. Organization Science, 7(4), 375-387.

. (1996b). Towards a knowledge-based theory of the firm. Strategic Management Journal, 17, 109-122.

Grassberger, R. G. (2004). The practice of kowledge management and its impact on new Mexico small and mid-sized organization. Unpublished thesis. The University of New Mexico.

Hair, J. F., Black, W. C., Babin, B. J., Anderson, R. E., \& Tatham, R. L. (2006). Multivariate data analysis (6th ed.). NJ: Pearson Education International.

Haksever, C. (1996). Total quality management in the small business environment. Business Horizons, 39(2), 33-40. 